\title{
Serum cholesterol linoleate levels in multiple sclerosis
}

\author{
R. W. R. BAKER, HAZEL SANDERS, R. H. S. THOMPSON, AND K. J. ZILKHA \\ From the Department of Chemical Pathology, Guy's Hospital Medical School, and the National Hospital, \\ Queen Square, London
}

The percentage composition of the free and esterified fatty acids in the total lipid extracts of samples of serum taken from 47 patients with multiple sclerosis and from 38 control subjects has recently been described (Baker, Thompson, and Zilkha, 1964). It was found that the percentage of linoleic acid was significantly reduced in the multiple sclerosis group taken as a whole. Furthermore, when the patients were graded according to the activity of the disease, the percentage of linoleic acid was found to fall progressively with increasing evidence of recent deterioration in the patients' condition; the mean percentage of linoleic acid in the patients placed in the grade showing the greatest deterioration was $18.6 \%$, compared with $25.6 \%$ in the control group.

Since it is known that the cholesterol ester fraction of the serum lipids contains a much higher proportion of linoleic acid than either the phospholipid or triglyceride fractions (Lewis, 1958; Luddy, Barford, Riemenschneider, and Evans, 1958; Tuna, Reckers, and Frantz, 1958; Wright, Pitt, and Morton, 1959; Riley and Nunn, 1960; Lawrie, McAlpine, Pirrie, and Rifkind, 1961), it was decided to compare the levels of cholesterol linoleate in serum from normal subjects and from patients with multiple sclerosis.

\section{SUBJECTS}

The subjects of the present study consisted of 23 controls and 35 patients with multiple sclerosis.

The controls included eight healthy subjects, five women and three men, aged 24 to 52 years (mean 33 years), and 15 'neurological controls', 10 women and five men, i.e., in-patients in the National Hospital, Queen Square, the Cheshire Foundation Home for the Chronic Sick (Copthorne, Sussex), and Guy's Hospital, suffering from neurological disorders other than multiple sclerosis (Table I), whose ages ranged from 13 to 54 years (mean 36 years).

The 35 patients with multiple sclerosis, aged 19 to 61 years (mean 38 years), comprised 22 in-patients (seven males and 15 females) from the same institutions as the controls, together with six female in-patients from the Dunoran Home, and seven out-patients (four males and
TABLE I

NEUROLOGICAL CONTROL SUBJECTS

\begin{tabular}{lcl} 
Subject & Age $(y r)$. & Diagnosis \\
\hline H.W. & 54 & Cerebrovascular disease \\
B.L. & 32 & Dermatomyositis \\
F.J. & 25 & Myasthenia gravis \\
C.C. & 13 & Subacute sclerosing leucoencephalitis \\
P.F. & 45 & Motor neurone disease \\
W.C. & 52 & Motor neurone disease \\
G.P. & 39 & Lumbar disc protrusion \\
D.P. & 26 & Epilepsy of late onset (since age 23 yr.) \\
I.G. & 37 & Epilepsy (since age 11 yr.) \\
T.C. & 37 & Epilepsy (since age 14 yr.) \\
S.L. & 42 & Polyneuritis \\
J.W. & 22 & Ocular sympathetic palsy ? Cause \\
V.F. & 52 & Motor neurone disease \\
H.D. & 38 & Dejerine Sottas' hypertrophic polyneuritis \\
G.B. & 36 & Huntington's chorea
\end{tabular}

three females) attending the National Hospital and Guy Hospital.

Blood $(20 \mathrm{ml}$.) was drawn from each subject from the antecubital vein after an overnight fast; in the case of the women it was drawn between approximately the twelfth and twentieth days of the menstrual cycle. For the most part the specimens were taken in pairs, one from a control and one from a patient with multiple sclerosis. The subsequent analyses were carried through 'blind', the analyst $\mathbb{\complement}$ being unaware of the identity of the specimens. Sera from 35 patients with multiple sclerosis and 23 controls were thus examined.

The neurological controls were chosen, as far as possible, so as to be of the same sex and of a similar age and weight, and showing a degree of physical handicap comparable to that of the multiple sclerosis patients. All patients in the study were taking a normal diet. Eight $\frac{0}{3}$ of the control subjects and 14 of the patients with multiple $\frac{3}{4}$. sclerosis had been included in our earlier study (Baker et al., 1964).

\section{ANALYTICAL METHODS}

TOTAL CHOLESTEROL ESTERS In all cases a lipid extract of N the serum was prepared by the method of Webster (1962). The total cholesterol esters were estimated either after $N$ precipitation of the free cholesterol with digitonin, as N described by Webster (1962), or after elution with diethyl $O$ 
ether from thin-layer silicic acid-CaSO${ }_{4}$ plates developed with $20 \%$ peroxide-free diisopropyl ether in hexane. The colour development was carried out as described by Webster except that smaller volumes of reagents were used and that the $\mathrm{H}_{2} \mathrm{SO}_{4}$ was added immediately after taking the tubes from the $80^{\circ} \mathrm{C}$. bath, after which the tubes were mixed quickly, well shaken, and allowed to cool out of direct sunlight. Standards of either recrystallized cholesterol stearate or cholesterol oleate, purified on a silicic acid column, were taken, together with blanks, through the whole procedure. All estimates were done in duplicate.

Cholesterol linoleate was separated from the other fatty acid esters of cholesterol by a modification of the method of Zöllner, Wolfram, and Amin (1962). To achieve satisfactory separation of the cholesterol esters by this technique it was found necessary to use very thin layers (1.2-1.6 mg. Kieselgel $\mathrm{G} / \mathrm{cm}^{2}$. plate), and to apply not more than $0.05 \mu$ mole total cholesterol esters in a streak $4 \mathrm{~cm}$. in length. Plates were developed with $1 \%$ diisopropyl ether in hexane.

After staining with iodine, the zones of silicic acid containing the separated groups of esters were scraped from the plates to give three fractions containing the following types of esters: fraction 1, saturated and monoenoic esters; fraction 2 , di-enoic esters; fraction 3 , triand poly-enoic esters.

The esters were then eluted from each of these three fractions with diethyl ether, and the colour development carried out by the addition of $0.4 \mathrm{ml}$. $\mathrm{FeCl}_{3}$ reagent and $0.3 \mathrm{ml}$. conc. $\mathrm{H}_{2} \mathrm{SO}_{4}$, the optical density being read in $1 \mathrm{~cm}$. micro-cells. From the readings obtained for these fractions the amount of cholesterol linoleate, i.e., fraction 2, was calculated as a percentage of the sum of all three fractions, and from our estimate of the total cholesterol esters, the absolute level of cholesterol linoleate was calculated in $\mu$ moles $/ \mathrm{ml}$. serum (method A).

To avoid staining with iodine which, if prolonged, may lead to changes in the percentages of fractions 1,2 , and 3 recovered from the plate, thin-layer plates impregnated with $\mathrm{AgNO}_{3}$, as described by Morris (1963), were used in the later stages of the work. The plates were prepared by spreading on each plate $(20 \times 5 \mathrm{~cm}$. $) 1 \mathrm{~g}$. silicic acid (Merck) incorporating $11 \% \mathrm{CaSO}_{4}$, shaken up in $3.2 \mathrm{ml}$. $0.1 \mathrm{~N} \mathrm{AgNO}_{3}$ containing $2.5 \mathrm{mg} . \%$ 2',7'-dichlorofluorescein. After applying the cholesterol esters (0.3-0.6 $\mu$ mole) the plates were developed in $50 \%$ diisopropyl ether in hexane, and the three fractions 1, 2 and 3, eluted, and estimated as described above, except that 5-fold volumes of reagents were used. Recoveries of total serum cholesterol esters from these plates averaged 94\% (22 experiments).

The use of $\mathrm{AgNO}_{3}$-impregnated plates necessitated the preliminary separation of cholesterol esters from free cholesterol; this was achieved either by precipitation with digitonin (method B), or more usually by separation on silicic acid-CaSO $\mathrm{Ca}_{4}$ thin-layer plates, using $20 \%$ peroxidefree diisopropyl ether in hexane as the running solvent (method C), after quantitative application of the whole of the lipid extracts. Recoveries from these plates of cholesterol oleate averaged $98 \%$ (five experiments). All estimations by methods $\mathrm{A}, \mathrm{B}$, or $\mathrm{C}$ were done in duplicate.

\section{RESULTS}

Since our estimations of serum cholesterol linoleate levels are derived from measurements of the level of total cholesterol esters, together with determination of the percentage of cholesterol linoleate in the total ester fractions, experiments have been carried out to satisfy ourselves as to (a) the validity of our estimates of total cholesterol esters, and (b) the accuracy of our determinations of the linoleate percentage.

Table II gives a comparison of the estimates of total cholesterol esters in a series of specimens carried out by the classical method of Sperry and Webb (1950) and by the Webster technique carried out either after precipitation of free cholesterol with digitonin or after separation on thin-layer plates. It will be seen that the results obtained with the three methods agree well.

\section{TABLE II}

TOTAL CHOLESTEROL ESTERS IN SERUM ( $\mu$ MOLES/ML.) ESTIMATED BY THE METHODS OF SPERRY AND WEBB AND OF WEBSTER

\begin{tabular}{|c|c|c|c|}
\hline \multirow[t]{2}{*}{ Serum No. } & \multirow{2}{*}{$\begin{array}{l}\text { Method of } \\
\text { Sperry and } \\
\text { Webb }(1950)\end{array}$} & \multicolumn{2}{|c|}{ Method of Webster (1962) } \\
\hline & & $\begin{array}{l}\text { Digitonin } \\
\text { Precipitation }\end{array}$ & $\begin{array}{l}\text { Thin-layer } \\
\text { Separation }\end{array}$ \\
\hline 1 & 4.92 & 5.02 & - \\
\hline 2 & $4 \cdot 52$ & $4 \cdot 50$ & - \\
\hline 3 & $5 \cdot 12$ & 4.76 & - \\
\hline 4 & - & $4 \cdot 13$ & $4 \cdot 14$ \\
\hline 5 & - & 5.04 & 4.94 \\
\hline 6 & - & 2.96 & 3.03 \\
\hline
\end{tabular}

The analyses reported in Table III show that the three methods which we have used for the estimation of the percentage of cholesterol linoleate in the total cholesterol esters give essentially the same results. Table III (A and B) also gives an indication of the degree of reproducibility of the individual methods.

TABLE III

PERCENTAGE OF CHOLESTEROL LINOLEATE IN THE TOTAL CHOLESTEROL ESTERS ESTIMATED BY METHODS A, B, AND C Percentage Cholesterol Linoleate by

\begin{tabular}{|c|c|c|c|}
\hline Serum No. & Method A & Method B & Method C \\
\hline 1 & $46 \cdot 9$ & $47 \cdot 2$ & - \\
\hline 2 & - & $48 \cdot 3$ & $48 \cdot 5$ \\
\hline
\end{tabular}

TABLE IIIA

AVERAGE PERCENTAGE DEVIATIONS OF INDIVIDUAL ESTIMATES FROM THE MEANS OF THE DUPLICATE ESTIMATES FOR CHOLESTEROL LINOLEATE

\begin{tabular}{lcc} 
Method & $\begin{array}{c}\text { Average Percentage } \\
\text { Deviation }\end{array}$ & $\begin{array}{l}\text { Maximum Percentage } \\
\text { Deviation }\end{array}$ \\
\hline A & $1.68(35)^{1}$ & $5 \cdot 11$ \\
B & $1.88(4)$ & 3.32 \\
C & $1.49(26)$ & 3.98
\end{tabular}

${ }^{1}$ Number of duplicate observations given in brackets. 
TABLE IIIB

REPEATED ESTIMATES OF PERCENTAGE CHOLESTEROL LINOLEATE IN TOTAL CHOLESTEROL ESTERS IN FOUR DIFFERENT SERA BY METHOD A

Serum

\begin{tabular}{|c|c|c|c|c|}
\hline First estimate & $\left.\begin{array}{l}49 \cdot 6 \\
48 \cdot 0\end{array}\right\} 48 \cdot 8$ & $\left.\begin{array}{l}44.2 \\
44.9\end{array}\right\} 44.5$ & $\left.\begin{array}{l}46 \cdot 3 \\
48 \cdot 2\end{array}\right\} 47 \cdot 3$ & $\left.\begin{array}{l}48 \cdot 4 \\
47 \cdot 1\end{array}\right\} 47 \cdot 8$ \\
\hline econd estimate & $\left.\begin{array}{l}46 \cdot 5 \\
47 \cdot 7\end{array}\right\} 47 \cdot 1$ & $\left.\begin{array}{l}42 \cdot 0 \\
42 \cdot 8\end{array}\right\} 42 \cdot 4$ & $\left.\begin{array}{l}48 \cdot 3 \\
51 \cdot 9\end{array}\right\} 50 \cdot 1$ & $\left.\begin{array}{l}48 \cdot 0 \\
46 \cdot 2\end{array}\right\} 47$ \\
\hline $\begin{array}{l}\text { Mean } \\
\text { Percentage difference } \\
\text { of each estimate from } \\
\text { the mean of the two } \\
\text { estimates }\end{array}$ & $48 \cdot 0$ & $43 \cdot 5$ & $48 \cdot 7$ & $47 \cdot 5$ \\
\hline
\end{tabular}

The di-enoic esters of cholesterol present in our fraction 2 (see under Methods) were shown by gas chromatographic examination of the fatty acid moieties to consist of at least $97 \%$ cholesterol linoleate.

The mean levels of total cholesterol esters and of cholesterol linoleate in the sera of the control subjects and patients with multiple sclerosis are shown in Table IV.

TABLE IV

MEAN VALUES FOR SERUM TOTAL CHOLESTEROL ESTERS AND CHOLESTEROL LINOLEATE ( $\mu$ MOLES/ML. \pm S.E.M.)

\begin{tabular}{|c|c|c|c|}
\hline & $\begin{array}{l}\text { Total } \\
\text { Cholesterol } \\
\text { Esters }\end{array}$ & $\begin{array}{l}\text { Cholesterol } \\
\text { Linoleate }\end{array}$ & $\begin{array}{l}\text { Cholesterol Lin- } \\
\text { oleate as Per- } \\
\text { centage of Total } \\
\text { Cholesterol } \\
\text { Esters }^{1}\end{array}$ \\
\hline \multirow{5}{*}{$\begin{array}{l}\text { Controls }(23)^{2} \\
\text { Multiple sclerosis } \\
\text { grade A (13) } \\
\text { Multiple sclerosis } \\
\text { grade B (14) } \\
\text { Multiple sclerosis } \\
\text { grade C (8) } \\
\text { All cases of } \\
\text { multiple } \\
\text { sclerosis (35) }\end{array}$} & $4.58 \pm 0.20$ & $2 \cdot 17 \pm 0.09$ & $47.5 \pm 0.94$ \\
\hline & $4.79 \pm 0.18$ & $2 \cdot 31 \pm 0.11$ & $48 \cdot 1 \pm 1 \cdot 47$ \\
\hline & $4 \cdot 11 \pm 0 \cdot 20$ & $1.86 \pm 0 \cdot 10$ & $46 \cdot 1 \pm 1 \cdot 51$ \\
\hline & $3.76 \pm 0.19$ & $1.52 \pm 0.06$ & $40.9 \pm 1.41$ \\
\hline & $4 \cdot 28 \pm 0 \cdot 13$ & $1.95 \pm 0.07$ & $45 \cdot 7 \pm 0.99$ \\
\hline \multicolumn{4}{|c|}{ Significance of differences between means } \\
\hline \multirow{3}{*}{$\begin{array}{l}\text { Controls v. } \\
\text { grade A } \\
\text { Controls v. } \\
\text { grade B } \\
\text { Controls v. } \\
\text { grade C } \\
\text { Controls v. all } \\
\text { cases of } \\
\text { multiple sclerosis }\end{array}$} & $\begin{array}{l}\text { Not } \\
\text { significant } \\
\text { Not } \\
\text { significant } \\
P<0.05\end{array}$ & $\begin{array}{l}\text { Not } \\
\text { significant } \\
\mathbf{P}<0.05\end{array}$ & $\begin{array}{l}\text { Not } \\
\text { significant } \\
\text { Not } \\
\text { significant } \\
P<0.001\end{array}$ \\
\hline & $P<0.05$ & $P<0.001$ & $P<0.001$ \\
\hline & $\begin{array}{l}\text { Not } \\
\text { significant }\end{array}$ & $\mathbf{P}=0.06$ & $\begin{array}{l}\text { Not } \\
\text { significant }\end{array}$ \\
\hline
\end{tabular}

As mentioned earlier the group of 23 controls contained both normal subjects and patients with neurological disorders other than primary demyelinating conditions. Since no significant difference in the levels of either total cholesterol esters or cholesterol linoleate was observable between the normal subjects and the neurological controls these two groups have been combined into the one group of 23 controls. Moreover, since no differences were observed between the sexes, male and female controls have not been treated separately. The individual values for the control group are shown in Table $\mathrm{V}$.

\section{TABLE V}

TOTAL CHOLESTEROL ESTERS AND CHOLESTEROL LINOLEATE ( $\mu$ MOLES/ML.) IN SERUM FROM CONTROL SUBJECTS

\begin{tabular}{|c|c|c|}
\hline Subject & $\begin{array}{l}\text { Total Cholesterol } \\
\text { Esters }\end{array}$ & $\begin{array}{l}\text { Cholesterol } \\
\text { Linoleate }\end{array}$ \\
\hline $\begin{array}{l}\text { Normal controls } \\
\text { B.W. } \\
\text { M.C. } \\
\text { G.N. } \\
\text { J.E. } \\
\text { S.B. } \\
\text { R.T. } \\
\text { R.L. } \\
\text { P.P. }\end{array}$ & $\begin{array}{l}4 \cdot 95 \\
4 \cdot 71 \\
4 \cdot 07 \\
3 \cdot 80 \\
3 \cdot 61 \\
5 \cdot 83 \\
3 \cdot 60 \\
5 \cdot 30\end{array}$ & $\begin{array}{l}2 \cdot 54 \\
2 \cdot 42 \\
2 \cdot 10 \\
1 \cdot 90 \\
1 \cdot 70 \\
2 \cdot 58 \\
1 \cdot 91 \\
2 \cdot 84\end{array}$ \\
\hline Mean \pm S.E.M. & $4.48 \pm 0.30$ & $2 \cdot 25 \pm 0.14$ \\
\hline $\begin{array}{l}\text { Neurological controls } \\
\text { H.W. } \\
\text { B.L. } \\
\text { F.J. } \\
\text { C.C. } \\
\text { P.F. } \\
\text { W.C. } \\
\text { G.P. } \\
\text { D.P. } \\
\text { I.G. } \\
\text { T.C. } \\
\text { S.L. } \\
\text { J.W. } \\
\text { V.F. } \\
\text { H.D. } \\
\text { G.B. } \\
\text { Mean } \pm \text { S.E.M. } \\
\text { Mean of all controls } \\
\text { I S.E.M. }\end{array}$ & $\begin{array}{l}6 \cdot 64 \\
5 \cdot 13 \\
3.93 \\
4 \cdot 29 \\
4 \cdot 02 \\
4.09 \\
4 \cdot 66 \\
3.02 \\
4 \cdot 14 \\
4 \cdot 99 \\
6 \cdot 60 \\
3.03 \\
4 \cdot 52 \\
4 \cdot 85 \\
5 \cdot 56 \\
4 \cdot 65 \pm 0 \cdot 25 \\
4 \cdot 58 \pm 0.20\end{array}$ & 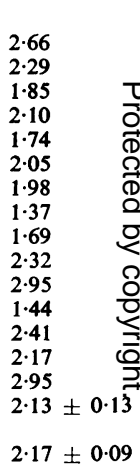 \\
\hline
\end{tabular}

As in our earlier work on the percentage of free $\stackrel{2}{\circ}$ and esterified linoleic acid in the serum lipids (Baker $\stackrel{\mathbb{Q}}{2}$ et al., 1964), the patients with multiple sclerosis $\overrightarrow{\overrightarrow{0}}$ have been graded according to the estimated activity 3 of the disease. Although we had formerly divided them into four grades (I-IV), in the present study we have examined only two patients in grade $\mathbf{I}, \overrightarrow{3}$ i.e., patients showing no evidence of clinical deterioration. We have therefore combined grades I and II $:$ and have classified the patients into only three grades as follows:GRADE A Patients showing only slight neurological disability and whose clinical condition was either 윽 stationary or showing only slight recent deterioration. All were ambulant and one (W.F.) was attending as an out-patient. GRADE B Moderate recent deterioration with evidence $\widetilde{N}$ of a more severe increase in disability; only one N (G.M.) was an out-patient and only one (D.B.) was ్్ confined to bed. 
GRADE C Rapid and extensive recent deterioration: all were in-patients and three (J.M., M.C., J.P.) were confined to bed.

The clinical assessment of activity of the disease, based on clinical evidence of deterioration in the month preceding examination, was carried out by one of us (K.J.Z.) without access at the time to the analytical results; in the majority of patients the assessment was made before the sample was drawn, the analysts being unaware of the classification given.

It will be seen that the mean level of total cholesterol esters in the overall group of patients with multiple sclerosis does not differ significantly from the mean of the control group. Furthermore, the patients in group B, that is to say, patients showing evidence of moderate recent deterioration, also showed no significant differences from the control group, although the patients with the most active forms of the disease (group C) did show a significant reduction $(P<0.05)$. The values obtained on the individual patients with multiple sclerosis are shown in Table VI.

TABLE VI

TOTAL CHOLESTEROL ESTERS AND CHOLESTEROL LINOLEATE ( $\mu$ MOLES/ML.) IN THE SERUM OF PATIENTS WITH MULTIPLE SCLEROSIS GRADED ACCORDING TO THE ESTIMATED ACTIVITY OF THE DISEASE

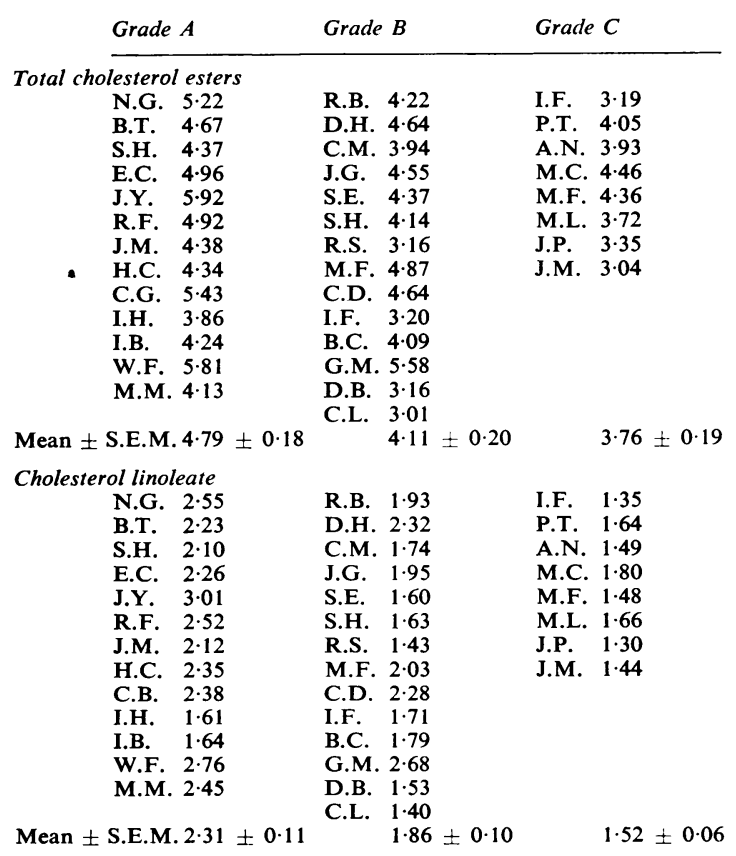

When compared with the levels of total cholesterol esters, the cholesterol linoleate levels in the patients with multiple sclerosis show a wider deviation from the control group, and are also reduced in a greater proportion of patients. Thus, patients in grade $\mathrm{C}$ show a mean level $1.52 \pm 0.06 \mu$ moles cholesterol linoleate $/ \mathrm{ml}$., compared with a level in the controls of $2.17 \pm 0.09 \mu \mathrm{moles} / \mathrm{ml}$., the difference between these means being highly significant $(P<0.001)$, while patients in grade $\mathrm{B}$ also differ, at a probability level of 0.05 , from the control mean.

It will be noticed that the mean value both of total cholesterol esters and of cholesterol linoleate is higher in the grade A patients than in the controls. As, however, these differences are not statistically significant it is not proposed to comment further on them.

\section{DISCUSSION}

Earlier work on the levels of free and esterified cholesterol in the serum of patients with multiple sclerosis had led to conflicting statements. Thus, the blood cholesterol level has been stated to be normal by several groups of workers (Fog, 1951; Wilmot and Swank, 1952; Chiavacci and Sperry, 1952) while others have reported that the levels of both total and esterified cholesterol are high (Jones, Jones, and Bunch, 1950; Dobin and Switzer, 1954). More recently Šercl, Kovařík, and Jícha (1961), in a study of 55 control subjects and 55 patients with multiple sclerosis, have found a reduction of total cholesterol from a mean value of $235 \pm 57 \mathrm{mg}$./100 $\mathrm{ml}$. in their controls to a value of $220 \pm 45 \mathrm{mg}$./100 $\mathrm{ml}$. in their group of patients, the esterified cholesterol also falling from a mean value of $147 \pm 44$ to a value of $128 \pm 36 \mathrm{mg} . / 100 \mathrm{ml}$.

The findings presented in this paper for the levels of total cholesterol esters agree with those of Šercl et al. (1961) in showing a small reduction in the mean level obtained in our overall group of patients with multiple sclerosis. The difference between this and the mean level in our group of controls is, however, not statistically significant; neither, as already reported (Thompson, 1965), have we found any significant abnormality in the free cholesterol level in our multiple sclerosis patients taken as a whole. It is indeed only in the group of patients showing clinical evidence of greatest activity of the disease process (grade $C$ ) that a significant reduction in the mean level of total cholesterol esters is found.

When we turn to the findings for cholesterol linoleate it will be seen that not only does the mean absolute level in $\mu \mathrm{moles} / \mathrm{ml}$. fall progressively with increasing activity of the disease, but that the percentage of cholesterol linoleate in the total cholesterol esters also falls, from a value of $47.5 \%$ in the controls to $46.1 \%$ in grade $\mathrm{B}$ and $40.9 \%$ in grade $\mathrm{C}$ (Table IV). Table VII shows that the changes 
TABLE VII

CHANGES IN MEAN LEVELS OF TOTAL CHOLESTEROL ESTERS AND CHOLESTEROL LINOLEATE ( $\mu$ MOLES/ML.) IN PATIENTS WITH MULTIPLE SCLEROSIS COMPARED WITH THE MEAN LEVELS IN THE CONTROL GROUP

\begin{tabular}{|c|c|c|}
\hline $\begin{array}{l}\text { Total } \\
\text { Cholesterol } \\
\text { Esters } \\
(T C)\end{array}$ & $\begin{array}{l}\text { Cholesterol } \\
\text { Linoleate } \\
(C L)\end{array}$ & $\begin{array}{l}\text { Change in CL a } \\
\text { Percentage of } \\
\text { Change in TC }\end{array}$ \\
\hline $\begin{array}{ll} & 0.21 \\
\text { B } & 0.47 \\
\text { C } & 0.82\end{array}$ & $\begin{array}{l}0.14 \\
0.31 \\
0.65\end{array}$ & $\begin{array}{l}67 \\
66 \\
79\end{array}$ \\
\hline 0.30 & 0.22 & 73 \\
\hline
\end{tabular}

in the mean levels of cholesterol linoleate in the various groups of patients with multiple sclerosis as compared with the control group account for about 65 to $80 \%$ of the changes observed in the total cholesterol esters. That is to say, since these changes in cholesterol esters in the blood in multiple sclerosis are centred predominantly round the linoleate ester, estimation of this must clearly provide a more sensitive and a more significant indication of these changes than does estimation of the total cholesterol esters. As in our earlier findings on the percentage of linoleic acid in the free and esterified fatty acids in serum (Baker et al., 1964), the level of cholesterol linoleate shows the greatest fall in those patients showing clear-cut evidence of clinical deterioration in the preceding month, five of the eight patients in group $\mathrm{C}$ showing levels of less than $1.5 \mu$ moles $/ \mathrm{ml}$.

Attention should be drawn to two patients, D.P. and J.W., of the group of neurological controls, who had cholesterol linoleate values of 1.37 and $1.44 \mu \mathrm{moles} / \mathrm{ml}$. respectively. D.P. was aged 26 years and was admitted with a history of epileptic seizures since the age of 23 years. There were no abnormal signs, and examination of the cerebrospinal fluid showed no abnormality. J.W. was aged 22 years and had a Horner's syndrome affecting the right eye, first noticed four years previously. There were no other abnormal signs, nor was the cerebrospinal fluid found to be abnormal. In neither case was there any suggestion in the previous history that the underlying pathology was due to a primary demyelinating process. Both patients were followed up for six months with no change in the clinical pictures being noted. In contrast to all our other neurological controls the possibility, although perhaps unlikely, remains that in these two patients the symptoms could have been the initial presenting manifestation of a primary demyelinating condition.

The results of this work support our earlier findings on the lowered percentage of linoleic acid in the mixture of free and esterified fatty acids in the serum of patients with multiple sclerosis. Using an entirely different technique we have now extended these findings by showing that the absolute level (in $\mu$ moles $/ \mathrm{ml}$.) of linoleic acid esterified with cholesterol is also reduced in the serum of patients with active multiple sclerosis. Our results again stress the need for an alignment of biochemical findings in multiple sclerosis with the clinical state of the patient and the activity of the disease.

On present evidence we cannot do more than speculate on the possible significance or the underlying mechanism of this fall in the level of cholesterol linoleate in the serum which appears to occur during or shortly after phases of active deterioration in patients with multiple sclerosis. Since, however, it is the unsaturated, linoleate ester which appears to be predominantly affected, the possibility of some abnormality of a transesterification process between cholesterol and the $\beta$-linked unsaturated fatty acid of a phospholipid must be considered. With this in mind the composition of the phospholipid fraction in the serum of patients with multiple sclerosis is now under investigation.

\section{SUMMARY}

Estimations have been made of the levels of totad $\vec{N}$ cholesterol esters and of cholesterol linoleate iro 응 serum from 35 patients with multiple sclerosis and 2 ? control subjects.

When the patients with multiple sclerosis wer graded according to the activity of the disease it was found that the level of cholesterol linoleate is ren duced in patients showing evidence of recent deterioration, the mean level in the eight patients showing the greatest deterioration being $1.52 \mu$ moles $/ \mathrm{ml}$. compared with a mean of $2.17 \mu$ moles $/ \mathrm{ml}$. in the control group.

The level of total cholesterol esters also showed a significant though less striking fall in the group showing the greatest deterioration.

We would like to thank the physicians in charge of the patients for their kind cooperation in this work. Our thanks are also due to the Multiple Sclerosis Society for a grant to assist this work, to the Medical Research Council for technical assistance, to Dr.A. N. Davison for a sample of cholesterol stearate, and to Miss P. A. Hawkes and Mrs. D. Paterson for their skilled technical help.

\section{REFERENCES}

Baker, R. W. R., Thompson, R. H. S., and Zilkha, K. J. (1964). Serum fatty acids in multiple sclerosis. J. Neurol. Neurosurg. Psychiat., 27, 408-414.

Chiavacci, L. V., and Sperry, W. M. (1952). Concentration of cholesterol and of lipid phosphorus in blood serum in multiple sclerosis. Arch. Neurol. Psychiat., 68, 37-42.

Dobin, N. B., and Switzer, J. L. (1954). Liver function and other blood chemistry tests in multiple sclerosis. Ibid., 71, 405-424. 
Fog, T. (1951). On the pathogenesis of multiple sclerosis. Acta psychiat. scand., suppl. 74, pp. 22-31.

Jones, H. H., Jones. H. H. Jr., and Bunch, L. D. (1950). Biochemical studies in multiple sclerosis. Ann. intern. Med., 33, 831-840.

Lawrie, T. D. V., McAlpine, S. G., Pirrie, R., and Rifkind, B. M. (1961). The fatty acid patterns of human serum in health. Clin. Sci., 20, 255-261.

Lewis, B. (1958). Composition of plasma cholesterol ester in relation to coronary-artery disease and dietary fat. Lancet, 2, 71-73.

Luddy, F. E., Barford, R. A., Riemenschneider, R. W., and Evans, J. D. (1958). Fatty acid composition of component lipides from human plasma and atheromas. J. biol. Chem., 232, 843-851.

Morris, L. J. (1963). Fractionation of cholesterol esters by thin-layer chromatography. J. Lipid Res., 4, 357-359.

Riley, C., and Nunn, R. F. (1960). The cholesterol esters circulating in human blood in health. Biochem. J., 74, 56-61.

Šrcl, M., Kovařik, J., and Jicha, J. (1961). Etude des valeurs des lipides du sérum sanguin en cas de sclérose en plaques. Acta neurol. scand., 37, 317-324.
Sperry, W. M., and Webb, M. (1950). A revision of the SchoenheimerSperry method for cholesterol determination. J. biol. Chem., 187, 97-106.

Thompson, R. H. S. (1965). The Scientific Basis of Medicine: Annual Reviews. In the press.

Tuna, N., Reckers, L. and Frantz, I. D. (1958). The fatty acids of total lipids and cholesterol esters from normal plasma and atheromatous plaques. J. clin. Invest., 37, 1153-1165.

Webster, D. (1962). The determination of total and ester cholesterol in whole blood, serum or plasma. Clin. chim. Acta, 7, 277284.

Wilmot, V. A., and Swank, R. L. (1952). The influence of low-fat diet on blood lipid levels in health and in multiple sclerosis. Amer. J. med. Sci., 223, 25-34.

Wright, A. S., Pitt, G. A. J., and Morton, R. A. (1959). Cholesteryl ester fatty acids in atheroma and plasma. Lancet, 2, 594-597.

Zöllner, N., Wolfram, G., and Amin, G. (1962). Uber die quantitative Auswertung von Dünnschichtchromatogrammen der Cholesterinester. Klin. Wschr., 40, 273-275. 